\title{
Make a Match Learning for English Conversation Skills of Students with Intellectual Disabilities
}

\author{
Desmiyanti $^{1}$, Yuanita ${ }^{2}$, Kaspul Anwar ${ }^{3}$ \\ Universitas Adiwangsa Jambi, Indonesia ${ }^{1,2}$ \\ STAI Ahsanta Jambi ${ }^{3}$ \\ Correspondence email: kaspulanwar.as@gmail.com
}

\section{Background:}

Abstract

This research aimed to discover the effectiveness of Make-A-Match model in improving the English conversation skills of students with intellectual disabilities. The participants of this research were 7th-grade students in Class C of SMPLB (Junior High School for Special Needs) Jambi

Methodology:

The data in this applied action research were obtained by using observation, interviews, and notes. This research was conducted in 3 cycles using four steps: planning, acting, observing, and reflecting in each cycle.

\section{Findings:}

The result showed that using the contextual approach to Make-A-Match model was sufficient to improve English conversation skills of students with intellectual disabilities. The students were more active, enthusiastic, and confident in uttering expressions without being anxious about making mistakes because the classroom atmosphere was relaxing and fun. This model also made students worked well together.

\section{Conclusion:}

Through this model, the teacher succeeds in encouraging students to apply English in their daily conversation.

Keywords:Contextual approach, make a match, speaking, students with intellectual disabilities

\begin{tabular}{l|ll}
\hline DOI & $:$ & http://dx.doi.org/10.24903/sj.v5i1.378 \\
\hline Received & $:$ & December 2019 \\
\hline Accepted & $:$ & March 2020 \\
\hline Published & $:$ & April 2020 \\
\hline Copyright Notice & $:$ & $\begin{array}{l}\text { Authors retain copyright and grant the journal right of first publication with the } \\
\text { work simultaneously licensed undera Creative Commons Attribution 4.0 International } \\
\text { License that allows others to share the work with an acknowledgment of the work's }\end{array}$ \\
$\begin{array}{ll}\text { authorship and initial publication in this journal. } \\
\text { C. (i) (O) }\end{array}$ \\
\hline
\end{tabular}




\section{INTRODUCTION}

The limited ability of students with intellectual disabilities or better known as children with special needs makes them less capable of making conversation, especially to speak in a foreign language like English, since they need special treatment so they can understand it better. As Sari, Binahayati, and Taftazani (2017) said that in the process of growth or development, they experience abnormalities or mental-intellectual disabilities compared to other children, so they need special services. Besides, this was also stated in Law on National Education System No. 20/2003 concerning the National Education System article 5, point 2, which states that citizens whose physical, emotional, mental, intellectual, and social disabilities are entitled to special education (Meria, 2015).

For teachers in Junior High School for Special Needs, teaching English as a foreign language, especially for the speaking skill, to students with intellectual disabilities, is a challenge. Although seems impossible, this is part of their responsibilities as educators who must be able to educate generations whatever their conditions are. This is also what the researchers found when they observed a class at SMPLB; the students seemed less interested when the English lesson was running. Teachers need to be as creative and flexible as possible in teaching English speaking skills to special needs students. Similarly, (Bešić, Paleczek, Rossmann, Krammer, \& Gasteiger-Klicpera, 2020; Kustawan, 2013; Snyder \& Ayres, 2020; Strogilos, Avramidis, Voulagka, \& Tragoulia, 2020) argued that people with intellectual disabilities have academic obstacles in such a way so that the learning services require curriculum modifications that are appropriate to their particular needs.

Based on the problems, the researchers found that the teachers needed a solution to improve the ability to speak in English for students with special needs. Hence, these students will be more easily understand the concepts contained in it. It was expected to involve all of them to be active without ignoring the appropriateness and usefulness of methods used with the material discussed. According to the researcher, one of the learning models that is considered suitable to learn English for students in SMPLB is to make a match model. According to (Arwin, Yunisrul, \& Zuardi, 2019; Putri, Mustapa, \& Gani, 2018; Yenni \& Ahda, 2019), make a match model is a technique of finding a partner, where students look for a pair of the card that they hold. The advantage of this technique is that students look for partners while learning a topic in a pleasant atmosphere. There are some features obtained from applying to make a match model, which was first stated in several previous studies. Zawil (2016) noted that this technique has several advantages. First, in answering a question given to 
students in the form of a card, each of them can be directly involved. Second, students' creativity can increase through matching the cards. Third, students are prevented from being bored during the teaching-learning process. Fourth, it can create an exciting classroom atmosphere. Besides, Nurpahmi (2017) argued that when teachers teach in a class, it is important to establish a fun and active class. Using "Make a Match" can make students more interactive and involve themselves in in-class activities (Huang, Hwang, \& Chen, 2016; Lompoliu \& Lompoliu, 2019; Rahayu, Mustaji, \& Setyowati, 2018). Further, Suprijono (2011) said that by using this technique, students become more interested and attentive to the teacher. They will not feel bored or become embarrassed when making mistakes in pronunciation. Teachers can minimize the difficulties they face in handling students when this technique is applied.

The difference between this research and some previous studies is that many previous researchers focus on improving English learning for public schools, while this research focuses on improving the quality of English learning of students with intellectual disabilities. It is the researcher's concern that the teachers of students with intellectual disabilities should be more sensitive on how their students can understand English and involve in interaction. The teacher should not focus on the vocabulary components only, in which vocabularies that are learned and memorized without practice will disappear. The teacher should be able to make these students practice what they have learned in their daily conversation.

In this study, the researchers explored the use of a match model through the contextual approach by using visual media in the form of picture cards which aim at helping the student to foster their interest and provide a relationship between the content of subject matter with the real world. Contextual learning, on the other hand, is a learning approach that aims at helping students add meaning in their learning with the context of their daily life experiences or expression. Furthermore, the contextual approach will significantly help students with intellectual disabilities in understanding the concept of foreign language expressions.

Nawas (2018) wrote that contextual learning is an approach that assists students to grasp what they are learning by connecting lessons with their lives' context. In line with this statement, Satriani, Emilia, and Gunawan (2012) stated that contextual learning is an approach that affirms students' interests and experiences, so they can easily understand the material. Further, Selvianiresa and Prabawanto (2017) described that the contextual learning is an approach that involves students to act in a learning process find concepts learned by connecting the material with the knowledge they have and experience in daily life. 
The primary purpose of this study is to reveal the description of the effectiveness of make a match as an alternative learning model for teachers to improve the ability of students with intellectual disabilities to speak English.

\section{METHODOLOGY}

This study was carried out towards physically and mentally disabled children in Jambi City and focused on students with mild intellectual disabilities. The participants of this study were seventh grade students at class C in SMPLB Jambi.

\subsection{The research procedure}

This Research was conducted in 4 stages, namely (1) planning, (2) implementation, (3) observation, and (4) reflection (Kemmis, McTaggart, \& Nixon, 2013). It was carried out in three cycles. After the reflection of the first cycle was done, new problems arose, so there must be re-planning, re-implementation, re-action, re-observation, and re-reflection to be done.

\section{FINDINGS}

In this case, the researchers, as the teachers applied, Make-A-Match model through the contextual approach by using the varied cards to teach greeting expressions. As a result, they immediately linked the learning material with students' daily lives or experiences when they were teaching these expressions and applying this learning model. By applying this model, the teacher required the students to find and practice the expressions. If students looked confused, the teacher would relate to their daily lives so they would not have difficulties in understanding the material (Nawas, 2018; Satriani et al., 2012; Selvianiresa \& Prabawanto, 2017). The implementation of making a match method in this study, that is: (1) The teacher provides several varied cards that are suitable for the topic to be taught. They are consisting of 2 types of cards (questions and answers). (2) Each student gets a card. (3) Each student thinks of the answers/questions from the card owned for 10 seconds. (4) During the accompaniment of music sounds, each student looks for a partner who has a card that matches the card he is holding. (5) Points will be given to students who are able to match the card before the time limit. (6) Every student who is mistaken in matching the cards, they must be able to recognize their mistakes and practice the phrases. If students look confused, the teacher can help students by linking the topic to their daily lives. (7) After one round, the cards are shuffled again so students get a different card from the previous one, and so on.

As illustrated in the step of making a make a match, the researchers as the teachers created some varied word cards by giving color and put the image on the answer/question card. This 
was done to make students felt more interested, and the game cards could present the meaning of the questions/answers from the card. The sample of varied cards in making a match model was illustrated in picture 1. Due to space limitations, only the relevant visual card was selected.

Figure 1. The sample display on Make a Match Model

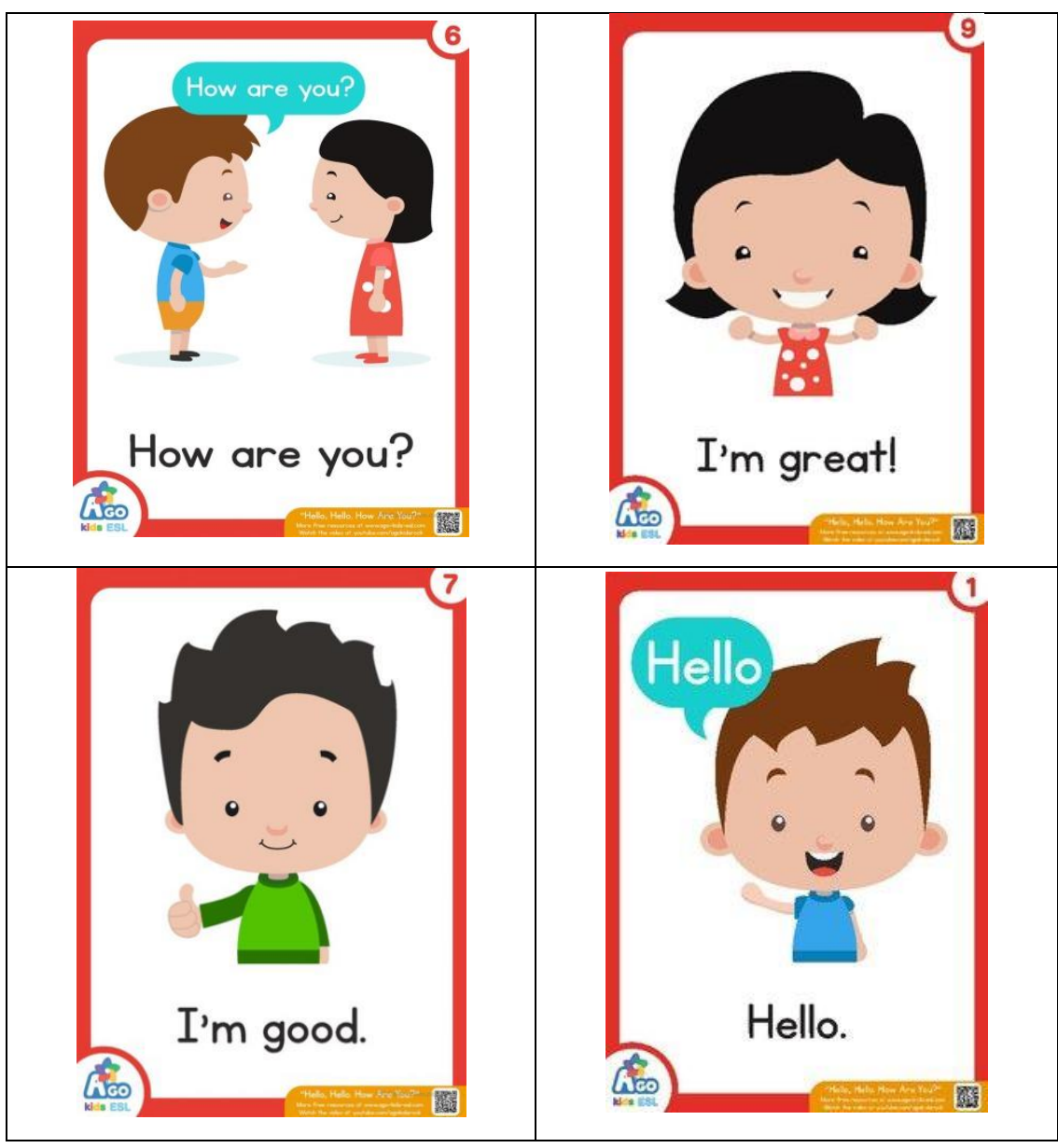

(https://www.bingobongokids.com)

There were several problems that this study found in applying make a match method at the beginning of learning activity in this study (cycle I). The study found that the students were still confused about playing this game and felt awkward when the students of the opposite sex held the pair of their cards. Then, some students were still shy to answer the questions from the teacher or when they did the speaking practice based on the cards they have. Further, some students did lack of participation in the learning and game process. This study also found that some students' errors to pronounce and express words.

To overcome those problems, the teachers in this study made improvements in the teaching strategies, providing motivation, and making more varied cards. These improvements were expected to improve the quality of the teaching and learning process. The impact of the improvement that this teacher does show that the students understand the flow of the game and 
can work together without discriminating against each other. These improvements also made the students more confident to speak and wanted to practice English expressions without fear. Even in cycle II, this study found that there were a few mistakes in pronunciation, or some words left unsaid, but only a few students did. Moreover, students were more active and could understand the material.

In cycle III, this study showed that there are no significant problems found. The only problem found was the students' lack of focus in the play round. This was caused by their high enthusiasm to win without paying attention to the cards anymore. Meanwhile, the more varied word cards have succeeded in making the students more interested and easier to understand the meaning of the questions/answers from the card.

Furthermore, from the interview data, the participant agreed that by applying this method, they did not feel bored in learning English because they could play while studying about a topic, such as greeting in English. By using make a match, they said that they could understand the concepts of words or sentences that were being studied better. Additionally, the participants in this study also said that they more easily understood the concepts of words or sentences they are being studies. The following is an example of the participant's comments in this regard:

"This game is very exciting. We can play while studying. Just find the right pair of cards and then express it. We also not bored and afraid to say English words because the atmosphere in our class is relaxed and fun".

\section{DISCUSSIONS}

The finding of this study demonstrated that make a match is effective strategy to guide the student, including the students with mild intellectual disabilities, to understand how to express the word. The findings of this study also collaborate the research conducted by Hidayah, Sujadi, and Pangadi (2014) who found that students with mild intellectual disabilities can be directed and educated in academics, including in reading, writing and speaking. It can be drawn from the finding of this study where the students could find a pair of cards and be able to practice the greeting expressions correctly. This implies that children who experience language disorders and have limited absorption of learning are still able to be guided and invited to communicate (Dharmawan \& Wahyuni, 2017).

This Model made students actively participate in the class and involved all students to play in matching cards. They have a responsibility to find a suitable card. This was in line with the opinion of Irwanto \& Nurpahmi (2017) in which was revealed that when teachers teach in class, it is important to make fun active classes. This method could make students in the class 
to be more interactive and involve themselves in the class activities. Further, the students are already brave to raise their hands and infer what they have learned.

On the other hand, this study also confirms that as long as the students are directed to understand the meaning of the language used, they will be able to convey messages or to communicate (Zawil, 2016). The teachers have also succeeded in encouraging the students to be brave in speaking practices and being able to respond. The classroom atmosphere that was relaxed and pleasant made the students were unafraid of making mistakes in pronunciation. Because the lessons were adapted to daily life, their expressions could be understood by people around. What the students have done showed that they were also able to communicate in English, although all the components were not optimal. Interestingly, the finding of the study also in line with Suprijono (2011), who found that using Make-A-Match technique in the learning process will make the students more interested and enthusiastic in the learning process and the teacher in the classroom (Jeremy Harmer, 2003; Mart, 2012; Nation \& Newton, 2008; Rayhan, 2014).

Furthermore, our findings should be considered as an alternative learning model for teachers to improve the ability of students with intellectual disabilities to speak English. In this case with frequent practice in saying and asking students to apply expressions in daily situations made them accustomed to pronouncing vocabulary. The classroom atmosphere that was relaxed and pleasant could make them more confident to practice English expressions without being anxious.

\section{CONCLUSION}

In short, the use of making a match model can improve English conversation between students with intellectual disabilities. The teacher has successfully implemented the speaking function where they could speak as interactions and transactions (Richards, 2009). In addition, through appropriate games that suit students' conditions, such as applying to make a match model, they were able to be active and understand the material. This implied that through this model, the teacher has succeeded in encouraging the students to apply the language they have learned in their daily lives.

\section{REFERENCES}

Arwin, A., Yunisrul, Y., \& Zuardi, Z. (2019). Learning Make A Match Using Prezi in Elementary School in Industry 4.0. In 5th International Conference on Education and Technology (ICET 2019). Atlantis Press. 
Bešić, E., Paleczek, L., Rossmann, P., Krammer, M., \& Gasteiger-Klicpera, B. (2020). Attitudes towards inclusion of refugee girls with and without disabilities in Austrian primary schools. International Journal of Inclusive Education. https://doi.org/10.1080/13603116.2018.1467976

Dharmawan, A., \& Wahyuni, A. (2017). Audio-video Based Reading Learning Model For Mentally-Retarded Students. Jurnal Kependidikan: Penelitian Inovasi Pembelajaran, $1(2)$.

Hidayah, M., Sujadi, I., \& Pangadi, P. (2014). Proses Berpikir Siswa Tunagrahita Ringan Dalam Memecahkan Masalah Matematika Bentuk Soal Cerita Pada Operasi Hitung Campuran.

Huang, Y.-M., Hwang, J.-P., \& Chen, S. Y. (2016). Matching/mismatching in web-based learning: a perspective based on cognitive styles and physiological factors. Interactive Learning Environments, 24(6), 1198-1214. https://doi.org/10.1080/10494820.2014.978791

Irwanto, \& Nurpahmi, S. (2017). Using Make-a Match to Improve the Students' Reading Comprehension at MTS Guppi Samata Gowa. ETERNAL (English, Teaching, Learning, and Research Journal), 3(2), 161-172.

Jeremy Harmer. (2003). The Practice of English Language Teaching. ELT Journal. https://doi.org/10.1093/elt/57.4.401

Kemmis, S., McTaggart, R., \& Nixon, R. (2013). The action research planner: Doing critical participatory action research. Springer.

Kustawan, D. (2013). Bimbingan dan konseling bagi anak berkebutuhan khusus. Jakarta: PT. Luxima Metro Media.

Lompoliu, B. B. A., \& Lompoliu, B. A. (2019). Implementation of the Make A Match Learning Model to Improve Student Learning Outcomes BT - 5th International Conference on Education and Technology (ICET 2019). Atlantis Press. https://doi.org/https://doi.org/10.2991/icet-19.2019.48

Mart, Ç. T. (2012). Developing speaking skills through reading. International Journal of English Linguistics, 2(6), 91.

Meria, A. (2015). Model Pembelajaran Agama Islam bagi Anak Tunagrahita di SDLBYPPLB Padang Sumatra Barat. TSAQAFAH, 11(2), 355-380.

Nation, I. S. P., \& Newton, J. (2008). Teaching ESL/EFL listening and speaking. Routledge.

Nawas, A. (2018). Contextual Teaching and Learning (CTL) Approach Through REACT Strategies On Improving The Students' Critical Thinking in Writing. International Journal of Management and Applied Science, 4(7), 46-49.

Putri, E. P. K., Mustapa, K., \& Gani, A. (2018). Effect of Cooperative Make a Match Learning Model on Student's Learning Outcomes on Electrolyte and Non-Electrolyte Solutions Topics. In First Indonesian Communication Forum of Teacher Training and Education Faculty Leaders International Conference on Education 2017 (ICE 2017). Atlantis Press.

Rahayu, I., Mustaji, M., \& Setyowati, R. R. N. (2018). Application of Make A Match Learning to Increase Learning Outcomes for Primary School BT - 2nd International Conference on Education Innovation (ICEI 2018). Atlantis Press. https://doi.org/https://doi.org/10.2991/icei-18.2018.5 
Rayhan, J. M. (2014). The Impact of Using Role Play Techniques on Improving Pupils' Speaking Skill for Primary School. Basic Education College Magazine For Educational and Humanities Sciences, (15), 516-530.

Richards, J. C. (2009). Teaching listening and speaking : from theory to practice. Singapore: SEAMEO Regional Language Centre.

Sari, S. F. M., Binahayati, B., \& Taftazani, B. M. (2017). Pendidikan Bagi Anak Tuna Grahita (Studi Kasus Tunagrahita Sedang di SLB N Purwakarta). Prosiding Penelitian Dan Pengabdian Kepada Masyarakat, 4(2).

Satriani, I., Emilia, E., \& Gunawan, H. (2012). Contextual teaching and learning approach to teaching writing. Indonesian Journal of Applied Linguistic, 2(1), 10-22.

Selvianiresa, D., \& Prabawanto, S. (2017). Contextual Teaching and Learning Approach of Mathematics in Primary Schools. In Journal of Physics: Conference Series (Vol. 895, p. 12171).

Snyder, S. M., \& Ayres, K. (2020). Investigating the usage of reading curriculum-based measurement (CBM-R) to formatively assess the basic reading skills of students with intellectual disability. Education and Training in Autism and Developmental Disabilities. Retrieved from https://www.scopus.com/inward/record.uri?eid=2-s2.085081237195\&partnerID=40\&md5=e24986dc3ba6098a5799e9698f488163

Strogilos, V., Avramidis, E., Voulagka, A., \& Tragoulia, E. (2020). Differentiated instruction for students with disabilities in early childhood co-taught classrooms: types and quality of modifications. International Journal of Inclusive Education. https://doi.org/10.1080/13603116.2018.1466928

Suprijono, A. (2011). Cooperative Learning; Teori dan Aplikasi Paikem. Yogyakarta: Pustaka Pelajar.

Yenni, I., \& Ahda, Y. (2019). Implementation of "Make a Match" Type of Cooperative Learning Model Assisted With Student Worksheets (Lkpd) to Improve VII Grade Students' Learning Competences in Natural Science Subject in SMPN 5 Padang.

Zawil, R. (2016). Using make a Match Technique to teach vocabulary. English Education Journal, 7(3), 311-328. 